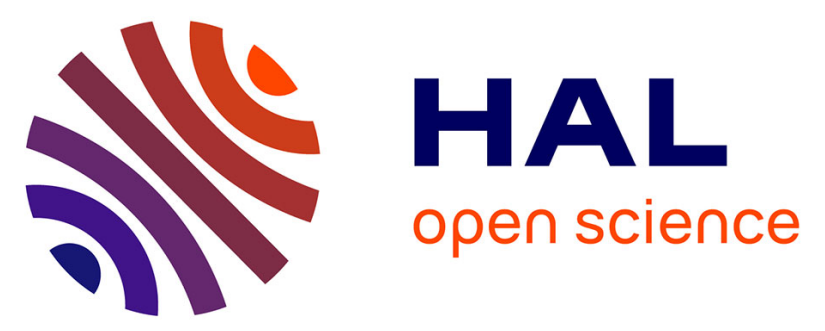

\title{
Fretting-corrosion between 316L SS and PMMA: Influence of ionic strength, protein and electrochemical conditions on material wear. Application to orthopaedic implants
}

Julie Pellier, Jean Geringer, Bernard Forest

\section{To cite this version:}

Julie Pellier, Jean Geringer, Bernard Forest. Fretting-corrosion between 316L SS and PMMA: Influence of ionic strength, protein and electrochemical conditions on material wear. Application to orthopaedic implants. Wear, 2011, 271 (9-10), pp.1563-1571. 10.1016/j.wear.2011.01.082 . hal00620859

\section{HAL Id: hal-00620859 \\ https://hal.science/hal-00620859}

Submitted on 9 Sep 2011

HAL is a multi-disciplinary open access archive for the deposit and dissemination of scientific research documents, whether they are published or not. The documents may come from teaching and research institutions in France or abroad, or from public or private research centers.
L'archive ouverte pluridisciplinaire HAL, est destinée au dépôt et à la diffusion de documents scientifiques de niveau recherche, publiés ou non, émanant des établissements d'enseignement et de recherche français ou étrangers, des laboratoires publics ou privés. 


\title{
Fretting-corrosion between 316L SS and PMMA: influence of ionic strength, protein and electrochemical conditions on material wear. Application to orthopedic implants.
}

\author{
J. Pellier, J. Geringer ${ }^{*}$, B. Forest \\ École Nationale Supérieure des Mines de Saint-Étienne (ENSM-SE), Centre Ingénierie \& Santé, UMR CNRS 5146 PECM, IFR 143 IFRESIS, \\ 158 cours Fauriel, 42023 SAINT-ETIENNE cedex 2, France \\ Received Date Line (to be inserted by Production) (8 pt)
}

\begin{abstract}
In biomedical field, fretting-corrosion between 316L SS femoral stem and bone cement is one of the significant causes of the hip prosthesis loosening. This article investigates wear by fretting-corrosion at the contact between 316L and PMMA. The influences of the ionic strength ( $\mathrm{NaCl}$ solutions from $10^{-3}$ to $\left.1 \mathrm{~mol} \cdot \mathrm{L}^{-1}\right)$, a model protein (albumin) and electrochemical conditions on contact behaviour are studied. At OCP (Open Circuit Potential) conditions, the chlorides concentration, i.e. the ionic strength, increases the 316 L wear; and albumin, concentration of $1 \mathrm{~g} . \mathrm{L}^{-1}$, does not play a significant role in total 316L wear. At cathodic applied potential $\mathrm{E}=-400 \mathrm{mV}(\mathrm{SCE})$, a threshold concentration of $10^{-1} \mathrm{~mol}^{-1} \mathrm{~L}^{-1} \mathrm{NaCl}$ solution), $\mathrm{C}_{\text {th }}$, indicates two behaviours: a protective effect below $\mathrm{C}_{\mathrm{th}}$, and an additional anodic dissolution above $\mathrm{C}_{\mathrm{th}}$. One might suggest that, beyond $\mathrm{C}_{\mathrm{th}}$, the passive layer is not efficient for protecting against the corrosion. At this potential, albumin reduces wear due to corrosion and amplifies mechanical wear induced by corrosion. Albumin seems to act as an anodic inhibitor. To determine the mechanisms of synergism, a "more cathodic" potential is applied, $\mathrm{E}=-800 \mathrm{mV}(\mathrm{SCE})$, during fretting-corrosion experiments. Consequently, the corrosive wear can be neglected and the mechanical wear can be only measured.
\end{abstract}

Keywords: Fretting-corrosion, 316L SS, PMMA, Ionic strength, Albumin.

\section{Introduction}

In Europe, each year, there are about 1 million hip replacements, and approximately the same number in USA. Nevertheless, after 10-15 years, approximately $10 \%$ of Total Hip Arthroplasties (THA) need a reintervention. Nowadays, the ageing of the population, injuries or diseases like arthrosis are public health issues. To avoid additional surgical reoperation and improve lifetime duration of implants, studies on orthopedic implants

*Corresponding author. Tel.: +33 477426 688; fax: +33 477421057.

E-mail address: pellier@emse.fr (J. Pellier), geringer@emse.fr (J. Geringer), forest@emse.fr (B. Forest) 
are needed. Three different metal alloys can be used for femoral stem: cobalt-chromium alloy, titanium alloy or austenitic stainless steel. We focus our attention on cemented hip prostheses. In 1960, in order to decrease the number of femoral stem debonding, Sir John Charnley decided to insert hip prostheses with poly(methyl methacrylate) called bone cement [1]. For a cemented prosthesis (Fig. 1), the austenitic stainless steel (316L SS alloy) is usually used for femoral stem thanks to its biocompatibility and high resistance against corrosion in biological environment without friction.

Because of the daily human gait and significant difference of mechanical properties (particularly, Young's moduli) between 316L SS and bone cement, stress shielding phenomenon appears. The metallic material and the polymer do not have the same strain properties, thereby leading to debonding between the femoral stem and the cement. It involves fretting (friction under small displacements, term precisely defined later) and friction. Finally, the upper part of femoral bone is unloaded and then becomes more susceptible to fracture; on the other hand, if bone around femoral stem tip is overloaded, it becomes stronger [2]. However, the bone cement acts as a "bumper" between femoral stem and bone, leveling peak forces acting around the prosthesis during the human gait.

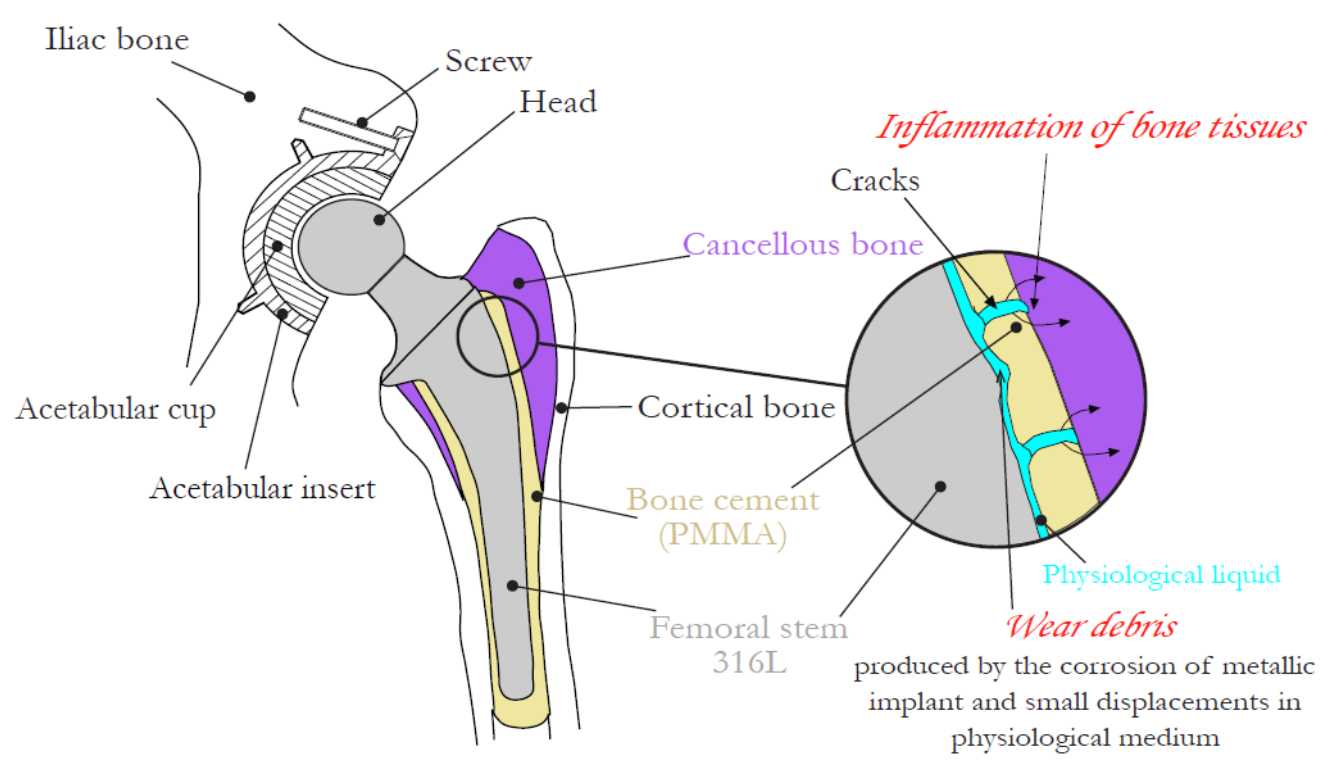

Fig. 1 Total hip joint cemented prosthesis components

Femoral stem debonding and consequently friction between femoral stem and bone cement leads to cement degradation and cracking (Fig. 1). Debris from bone cement and femoral stem (metal oxides and ions) go through cement up to bone tissues [3]. Thus, the disturbance of osteoblasts cell activity and the tissue inflammation, respectively caused by bone cement particles and metallic oxides and ions, involve implant reoperation. It is the reason why fretting-corrosion between femoral stem and bone cement, particles generation, is one of the most 
important causes of reintervention [4,5]. Consequently, fretting-corrosion experiments were carried out for understanding corrosion and mechanical influences, and improving the lifetime of implants.

Fretting means friction under small reciprocal displacements, and the amplitude of displacement is lower than contact width. Rubin et al. found out, by numerical modeling, the amplitude of displacement is about $50 \mu \mathrm{m}$ (depending on the location) between bone and stem under applied stresses during human gait [6]. Nonetheless, the displacement amplitude between bone cement and femoral stem is supposed identical [7].

Wear of a metallic material under the conjugated effects of a mechanical solicitation (friction or fretting in this case) and of corrosion by a medium (physiological liquid) is named tribocorrosion [8]. Thus, frettingcorrosion is fretting in a corrosive environment for a metal alloy. This phenomenon leads to passive layer destruction and debris generation, principally metal oxides (Fig. 2) and polymer particles [9-11].

The fretting-corrosion phenomenon between femoral stem and bone cement is modelized by frettingcorrosion between a 316L SS sample (the same material as that of femoral stem) and PMMA which has the same mechanical properties as bone cement. This polymer was chosen because of its optical transparency. In that way, a direct observation of the contact zone and the debris evolution between materials at contact are investigated.
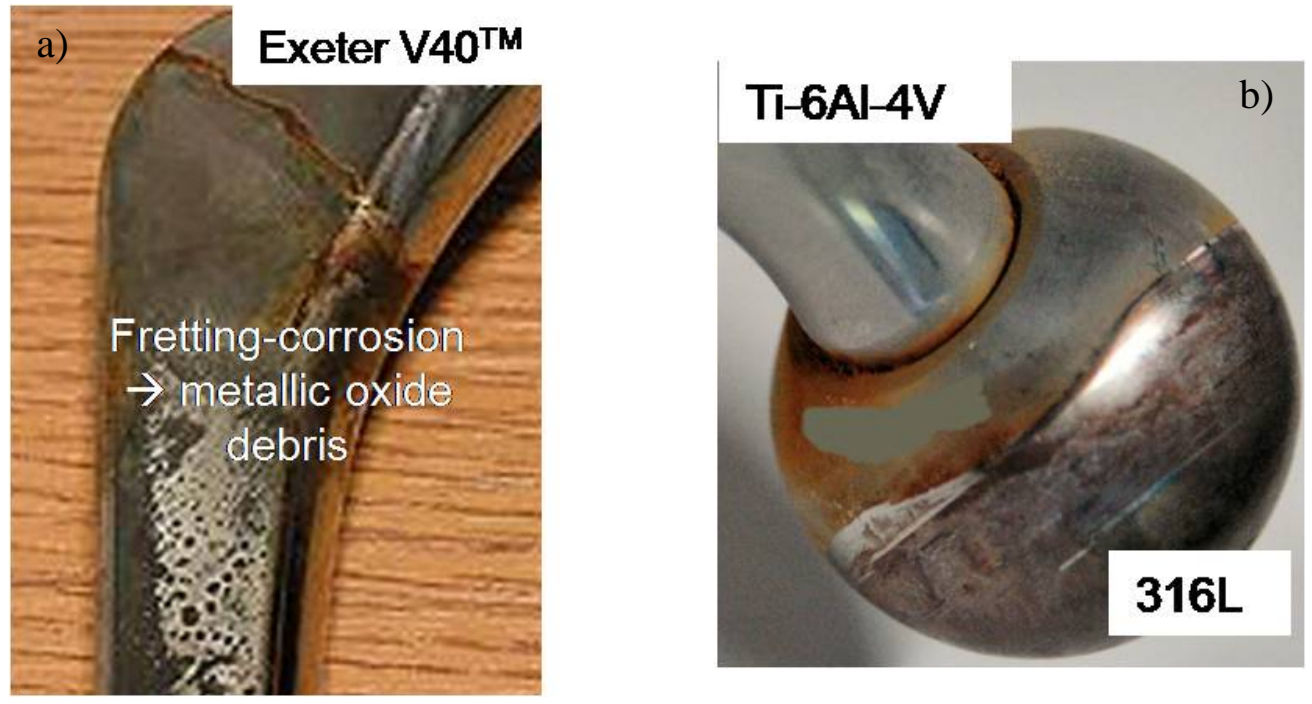

Fig. 2 (a) Fretting-corrosion between femoral stem (Exeter V40 ${ }^{\mathrm{TM}}$ ) and bone cement [7]; (b) fretting-corrosion between a head (316L) and a femoral neck (Ti-6Al-4V)

Physiological liquid components are various, including numerous ions and proteins. Each component plays a different role in double layer constitution at material surface. To separate the contribution of each component, fretting-corrosion tests between 316L and PMMA were investigated in different solutions. The first one is Ringer solution. Its composition is close to physiological liquid. However, this solution is too complex: each ion may play a different role during a fretting-corrosion test. That's why this work focuses on 1:1 solutions, i.e. solutions constituted by only $\mathrm{NaCl}$. In this way, the role of chlorides on the passivity behaviour of 316L can be determined 
during a fretting-corrosion test. To compare corrosion and mechanical behaviours in these solutions, this study aims at investigating the influence of ionic strength I:

$$
I=\frac{1}{2} \sum_{i} z_{i}^{2} C_{i}
$$

where $\mathrm{z}_{\mathrm{i}}$ : ion charge; $\mathrm{C}_{\mathrm{i}}$ : ion concentration. Indeed, the ionic strength can interfere in the double layer constitution by the solution content and in the "attraction-repulsion" phenomenon betweenthe contact between two materials [12].

The role of proteins is also investigated. This work focuses on albumin, which is the main protein of blood plasma. Afonso et al. [13] have shown that bovine serum albumin, in $\mathrm{NaCl} 0.15 \mathrm{M}$ at $37{ }^{\circ} \mathrm{C}$, on UNS S31254 stainless steel, stops anodic dissolution of chromium and decreases iron dissolution. Valero Vidal et al. [14] worked with 316L and CoCrMo alloy in $\mathrm{NaCl} 0.14 \mathrm{M}$ at $37^{\circ} \mathrm{C}$, with or without albumin $\left(0.5\right.$ g.L $\left.\mathrm{L}^{-1}\right)$. They showed that for 316L, albumin does not modify open circuit potential (OCP) but it acts as an anodic inhibitor at applied potential, i.e. it increases cathodic reaction rate. Albumin also tends to decrease the polarization resistance, removing oxides from a protective layer and then exhibiting a material surface from corrosion. For CoCrMo alloy, albumin acts as a cathodic inhibitor and also increases anodic reaction rate, i.e. it accelerates corrosion. During a fretting-corrosion test between a Ti-6Al-4V alloy and alumina in $\mathrm{pH}$ buffered saline solutions at $37{ }^{\circ} \mathrm{C}$, Hiromoto et al. [15] showed that albumin (1 g.L ${ }^{-1}$ bovine serum albumin) mostly modifies cathodic behaviour and acts as a cathodic inhibitor, i.e. it reduces cathodic reaction rate. From a mechanical point of view, albumin does not affect friction coefficient $\mu$ and wear volume.

During a fretting-corrosion test, material wear is a combination of mechanical wear (fretting) and corrosion. However, the total material loss(W) is not only determined as the sum of two different material losses: (i) material loss due to mechanical wear obtained without the influence of corrosion $\left(\mathrm{W}_{\mathrm{m}}\right)$ and (ii) the material loss due to corrosion obtained without fretting action $\left(\mathrm{W}_{\mathrm{c}}\right)$. There is a synergistic effect between corrosion wear and mechanical wear. The synergy term $(\Delta \mathrm{W})$ means that corrosion increases wear due to fretting $\left(\Delta \mathrm{W}_{\mathrm{cm}}\right)$ and friction increases wear due to corrosion $\left(\Delta \mathrm{W}_{\mathrm{mc}}\right)[16,17]$.

$$
\mathrm{W}=\mathrm{W}_{\mathrm{m}}+\mathrm{W}_{\mathrm{c}}+\Delta \mathrm{W}=\mathrm{W}_{\mathrm{m}}+\mathrm{W}_{\mathrm{c}}+\left(\Delta \mathrm{W}_{\mathrm{cm}}+\Delta \mathrm{W}_{\mathrm{mc}}\right)
$$

This work aims at understanding the role of mechanical action and corrosion on a synergy term, and also calculating each of these terms for a fretting-corrosion test. In a first place, we focus on the percentage of wear due to corrosion obtained from the wear volume due to corrosion $V_{\text {corr }}\left(\mathrm{cm}^{3}\right)$, and the percentage can be found out with Faraday's law:

$$
\% \text { corrosive wear }=\frac{V_{\text {corr }}}{W} * 100 \text { with } \quad V_{\text {corr }}=\frac{1}{F} * \frac{M}{n \rho} * i * t
$$


where $F$ is Faraday constant $\left(F=96500 \mathrm{C} \cdot \mathrm{mol}^{-1}\right), M$ is the molecular weight $\left(M=56.39 \mathrm{~g} \cdot \mathrm{mol}^{-1}\right), n$ is the number of electrons involved in the anodic process ( $n=2$, hypothesis), $t$ is the total duration of the fretting-corrosion test ( $t=14,400 \mathrm{~s}), \rho$ is density $\left(\rho=8 \mathrm{~g} \cdot \mathrm{cm}^{-3}\right)$ and $i(\mathrm{~A})$ is the difference between the average current during fretting and the current after fretting.

Three electrochemical conditions were investigated for this study. First, the Open Circuit Potential (OCP) condition allows being as close as possible to the in vivo conditions. However, no information on current is available at OCP. Thus, fretting-corrosion tests are also carried out at cathodic applied potentials. - $400 \mathrm{mV}$ (SCE) is a threshold potential for anodic and cathodic transition of current. To remove (or to neglect) corrosion and to only obtain mechanical wear $\left(\mathrm{W}_{\mathrm{m}}\right)$, the cathodic potential of $-800 \mathrm{mV}(\mathrm{SCE})$ is chosen. For each electrochemical condition, the role and the influence of albumin are investigated.

\section{Materials and methods}

\subsection{Materials}

The 316L femoral stem is modeled by a plane 316L SS sample: $9 \mathrm{~mm}$ x $9 \mathrm{~mm}$ x $20 \mathrm{~mm}$ parallelepiped. One of the flat parts (9 mm x $20 \mathrm{~mm}$ ) was polished with diamond paste down to $1 \mu \mathrm{m}$. This frictional surface exhibits $3 \mathrm{D}$ roughness $\left(\mathrm{S}_{\mathrm{a}}\right)$ of about $10 \pm 2 \mathrm{~nm}$ (area of $1 \times 2 \mathrm{~mm}$, Veeco ${ }^{\mathrm{TM}}$ optic profilometer).

The bone cement, involved in THA, is modeled by a cylindrical PMMA, a polymer which has the same mechanical properties as those of bone cement. A sample maintains the length of $15 \mathrm{~mm}$ and the radius of curvature of $10 \mathrm{~mm}$. The cylindrical face was polished with $3 \mu \mathrm{m}$ diamond solution, Altuglass Polish 1 and $2^{\circledR}$ and colloidal solution of silica (particles size of $0.06 \mu \mathrm{m}$ ). The 3D roughness $\left(S_{a}\right)$ is about $35 \pm 5 \mathrm{~nm}$.

The geometry of the contact, cylinder/plane, allows a better control of contact pressure and width. Before the fretting-corrosion test, 316L SS and PMMA samples were stored at least 24 hours in a desiccator. The 316L sample is electrically insulated with Zircalloy alloy sheets and some varnish.

The composition of the 316L austenitic stainless steel (X2CrNiMo17-12, improved cleanliness and very low carbon content) is in accordance with ISO standard 5832-1 (Table 1). Mechanical properties of both materials are shown in Table 2.

Table 1 Chemical composition of $316 \mathrm{~L}$ stainless steel

\begin{tabular}{lcccccccccc}
\hline Elements & $\mathrm{Cr}$ & $\mathrm{Ni}$ & $\mathrm{Mo}$ & $\mathrm{Mn}$ & $\mathrm{Si}$ & $\mathrm{Co}$ & $\mathrm{C}$ & $\mathrm{Cu}$ & $\mathrm{S}$ & $\mathrm{Fe}$ \\
\hline Composition $(\% \mathrm{w} / \mathrm{w})$ & 17.4 & 13.0 & 2.6 & 1.73 & 0.66 & 0.20 & 0.0165 & 0.097 & $<0.001$ & Balance \\
\hline
\end{tabular}


Table 2 Mechanical properties of tested materials: 316L stainless steel and PMMA, *: obtained by ultrasonic measurements;

**: manufacturer data

\begin{tabular}{lcccc}
\hline $\begin{array}{c}\text { Mechanical } \\
\text { properties }\end{array}$ & $\begin{array}{c}\text { Young's modulus } \\
\mathrm{E}(\mathrm{GPa})^{*}\end{array}$ & $\begin{array}{c}\text { Poisson's } \\
\text { ratio } v^{*}\end{array}$ & $\begin{array}{c}\text { Yield stress } \\
(\mathrm{MPa})^{* *}\end{array}$ & $\begin{array}{c}\text { Ultimate tensile } \\
\text { strength (MPa)** }\end{array}$ \\
\hline 316L & 197 & 0.30 & 280 & 635 \\
\hline PMMA & 2.5 & 0.39 & 65 & 75 \\
\hline
\end{tabular}

\subsection{Solutions}

Two types of solution are used: Ringer solution (composition in Table 3) and $\mathrm{NaCl}$ solution, with concentrations of $10^{-3}, 10^{-2}, 10^{-1}$ and $1 \mathrm{~mol} . \mathrm{L}^{-1}$. Room temperature was of $22 \pm 1{ }^{\circ} \mathrm{C}$. To understand influence of proteins on fretting behaviour, albumin of 1 g. $\mathrm{L}^{-1}$ was added in each saline solution.

Table 3 Ringer solution composition

\begin{tabular}{lcccc}
\hline & $\mathrm{NaCl}$ & $\mathrm{KCl}$ & $\mathrm{CaCl}_{2}$ & $\mathrm{NaHCO}_{3}$ \\
\hline Concentration (g.L & -1 \\
\hline
\end{tabular}

\subsection{Test device}

To reproduce fretting-corrosion phenomenon, micro-displacements measured in vivo (about $50 \mu \mathrm{m}$ ) and stresses applied in vivo (between 7 and $30 \mathrm{MPa}$ ) [6] must be replicated. A specific device (Fig. 3), conceived and developed in collaboration between ENSM-SE and Böse, was used for fretting-corrosion tests. An electromagnetic motor, first tried for fretting-corrosion, let us obtain the same results as those delivered by the device used previously [9-11]. The load cell is a piezoelectric transducer and the displacement measurer is a capacitive sensor.

The mechanical parameters of fretting-corrosion tests are realistic:

- $\quad$ the applied normal load (P) was $127.5 \mathrm{~N}$, i.e. a pressure of about $22 \mathrm{MPa}$, which is spread from 7 to $30 \mathrm{MPa}$, range of pressure applied in vivo [6];

- the amplitude of displacement was $\pm 40 \mu \mathrm{m}$, close to the in vivo displacement [6]. Moreover, the displacement is sinusoidal and the frequency is $1 \mathrm{~Hz}$, i.e. one cycle equals one second, corresponding to the frequency of the gait cycle.

For these mechanical values, the gross slip condition was checked.

To identify actual displacement $\delta$ between both materials, the accommodation of the device must be considered. Based on the hypothesis that there is an elastic behaviour with compliance $\mathrm{C}_{\mathrm{s}}$, the actual displacement $\delta$ is: $\delta=\delta_{\mathrm{r}}-\delta_{\mathrm{acc}}=\delta_{\mathrm{r}}-\mathrm{C}_{\mathrm{s}} * \mathrm{Q}$, where $\delta_{\mathrm{r}}$ and $\delta_{\mathrm{acc}}$ are respectively the monitored and accommodated displacements, and $\mathrm{Q}$ is the tangential load [18]. 
For electrochemical measurements (OCP), current density and Electrochemical Impedance Spectroscopy (EIS), a PARSTAT 2263 potentiostat with a three-electrode set up was used:

- the working electrode was the stainless steel sample,

- the counter electrode was a circular wire of Pt having the diameter of about $60 \mathrm{~mm}$,

- the reference electrode was a Saturated Calomel Electrode (SCE, $\mathrm{E}=+246 \mathrm{mV}(\mathrm{SHE})$ at $\left.\mathrm{T}=22^{\circ} \mathrm{C}\right)$.

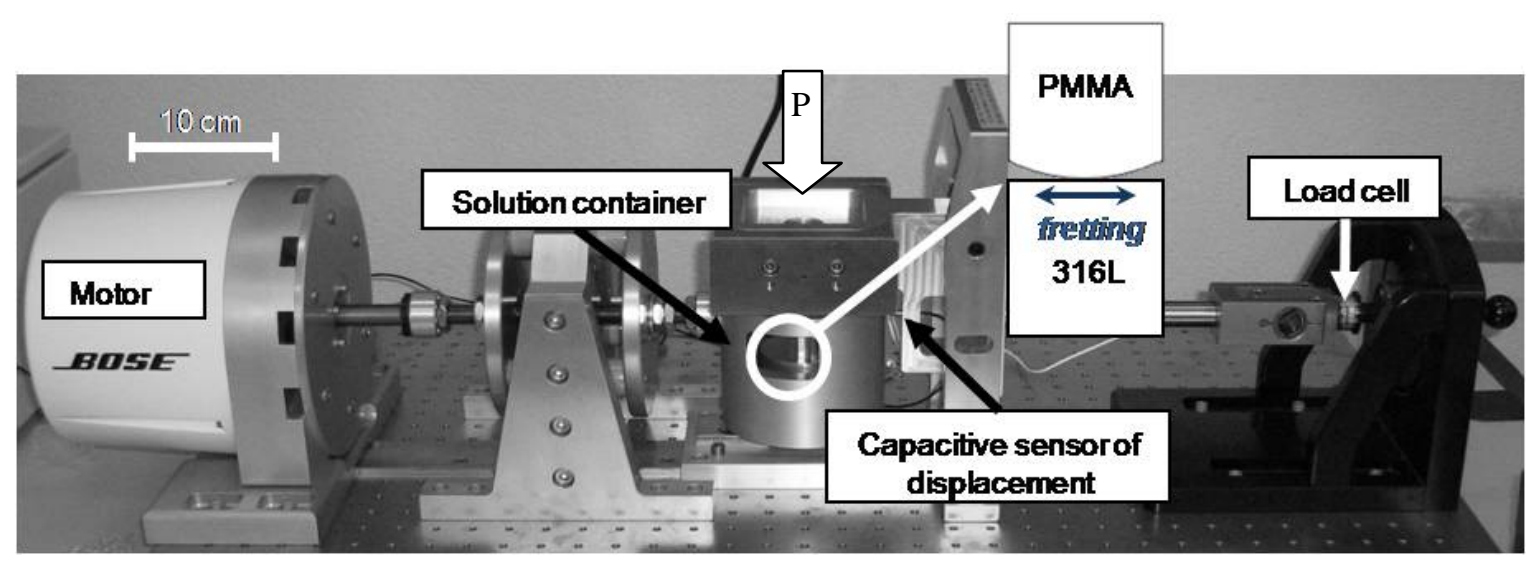

Fig. 3 Fretting-corrosion device: ENSM-SE and Böse prototype

EIS measurements were investigated from $10^{5} \mathrm{~Hz}$ to $10^{-1} \mathrm{~Hz}$ at a rate of 10 measurement frequencies/decade, with an AC amplitude of $10 \mathrm{mV}$. The potential was equal to OCP determined before EIS measurements or to applied potential (-400 or $-800 \mathrm{mV}(\mathrm{SCE})$ in our case). During friction tests, because of the non-stationarity conditions, EIS measurements should not be performed for actual values, but only the evolution of electrical parameters was considered [19]. One may notice that regular EIS measurements, during the fretting phase, have no influence on OCP or on current values after the EIS measurements.

For each electrochemical condition, OCP or cathodic applied potential (-400 and -800 mV(SCE)), two experiments (steps defined in Table 4) were carried out for all solutions with or without albumin. 
400 or $-800 \mathrm{mV}(\mathrm{SCE}))$

\begin{tabular}{ccc}
\hline $\begin{array}{c}\text { Electrochemical } \\
\text { conditions }\end{array}$ & OCP & $\begin{array}{c}\text { Potential applied: } \\
-400 \text { or }-800 \mathrm{mV}(\mathrm{SCE})\end{array}$ \\
\hline Step 1 & Cathodic polarization: $-1 \mathrm{~V}$ (SCE), 5 min \\
\hline Step 2 & without fretting: $1 \mathrm{~h}+$ EIS & without fretting: $10 \mathrm{~min}+$ EIS \\
\hline Step 3 & with fretting: $4 \mathrm{~h}+10$ EIS regular distribution \\
\hline Step 4 & $\begin{array}{c}\text { without fretting: } 14 \mathrm{~h}+2 \text { EIS after } \\
\text { fretting stop and } 1 \text { EIS after } 14 \mathrm{~h}\end{array}$ & $\begin{array}{c}\text { without fretting: } 10 \mathrm{~min}+2 \text { EIS } \\
\text { after fretting stop }\end{array}$ \\
\hline Step 5 & & $\begin{array}{c}\text { without fretting: } 14 \mathrm{~h} \text { OCP } \\
\text { measurement and } 1 \text { EIS after } 14 \mathrm{~h}\end{array}$ \\
\hline
\end{tabular}

\subsection{Wear profiles}

Thanks to Veeco ${ }^{\mathrm{TM}}$ WYKO NT9100 optic profilometer, the measurements of the total wear volumes for 316L and PMMA were performed. Three measurements were carried out on 316L and PMMA surfaces. The total wear volume was thus extrapolated for the total wear track length $(15 \mathrm{~mm})$. This value was compared with the total wear made on the whole length of the track. The wear volume error is about $10 \%$. Raw data were filtered by an automatic cylindrical shape.

\section{Results}

\subsection{Open Circuit Potential conditions}

\subsubsection{OCP evolution}

After cathodic polarization of $5 \mathrm{~min}$ at $-1 \mathrm{~V}(\mathrm{SCE})$, the open circuit potential (OCP) is recorded without fretting during 1 hour (steps described in Table 4, OCP evolution on Fig. 4). From the beginning of fretting, OCP is significantly decreased and then slightly stabilized. Instantly after the end of fretting, OCP nearly recovers the value before fretting. At regular intervals (every 20 minutes), the polarization resistance $\left(R_{p}\right)$ is determined with Electrochemical Impedance Spectroscopy (EIS) in order to investigate the behaviour of the metal surface. $R_{p}$ is extracted from the simple electrical circuit: $\mathrm{R}_{\text {sol }}\left(\mathrm{CPE} / / \mathrm{R}_{\mathrm{p}}\right)$, $\mathrm{R}_{\text {sol }}$ is the solution resistance, CPE is a Constant Phase Element and $R_{p}$ is the polarization resistance (resistances of the passive layer and the double layer at high frequencies). 


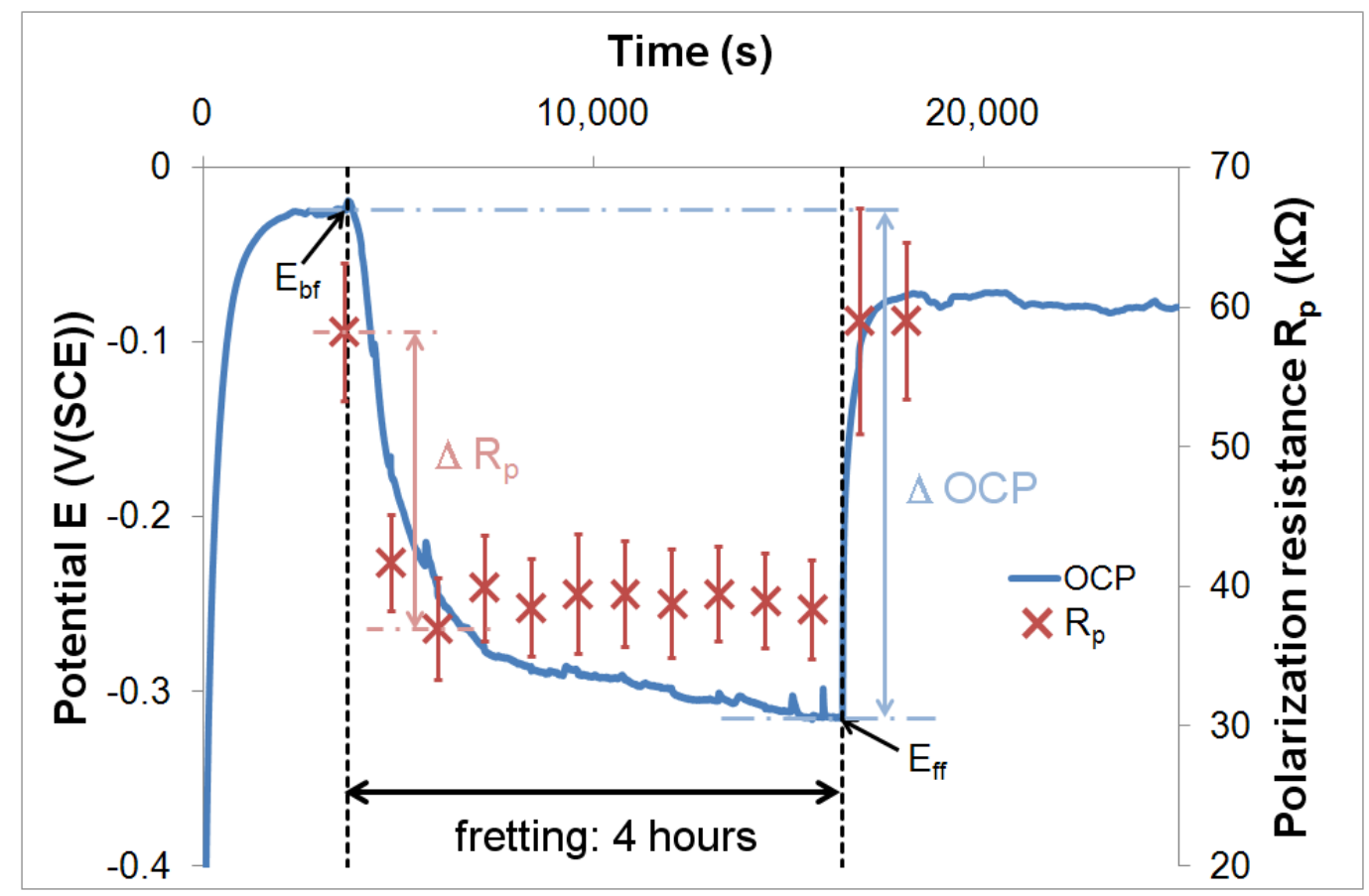

Fig. 4 Detail of experiment: OCP measurement before, during and after fretting and $\mathrm{R}_{\mathrm{p}}$ measurements from EIS. $\Delta \mathrm{R}_{\mathrm{p}}$ : difference between $R_{p}$ before and $R_{p}$ after 2400 cycles of fretting; $\triangle O C P$ : difference between OCP before fretting $\left(E_{b f}\right)$ and OCP at the end of fretting $\left(\mathrm{E}_{\mathrm{ff}}\right)$. Solution is constituted by $\mathrm{NaCl} 10^{-3} \mathrm{~mol} \cdot \mathrm{L}^{-1}$, displacement amplitude is of $\pm 40 \mu \mathrm{m}, 1$ cycle is equal to 1 second

Fig. 4 exhibits OCP and $\mathrm{R}_{\mathrm{p}}$ values in a $\mathrm{NaCl}$ solution of $10^{-3}$ mol. $\mathrm{L}^{-1}$. It is worth noting OCP and $\mathrm{R}_{\mathrm{p}}$ evolutions are the same as those of other solutions, only $\triangle \mathrm{OCP}$ and $\Delta \mathrm{R}_{\mathrm{p}}$ vary in accordance with the different solutions (Fig. 5).

Fig. 5 exhibits the decrease of $\triangle \mathrm{OCP}$ and $\Delta \mathrm{R}_{\mathrm{p}}$ according to the ionic strength. Both electrical values are consistent and they are related to the evolution of the contact submitted to fretting, i.e. less passive behaviour of the AISI 316L SS.

\subsubsection{Mechanical behaviour}

From a mechanical point of view, the dissipated energy $\left(E_{d}\right)$ during one cycle, which corresponds to the mechanical work of the tangential force, was monitored. For the total duration of the test, the cumulated dissipated energy $\left(E_{d c}\right)$, i.e. the sum of $E_{d}$ for each cycle ( 1 cycle $=1$ second), was calculated. The cumulated dissipated energy during fretting increases with ionic strength (Fig. 6). One may notice that experiments were investigated at two compliances. This fact substantiates that, the dissipated energy variation is controlled by the composition of the solution, not the mechanical device. 


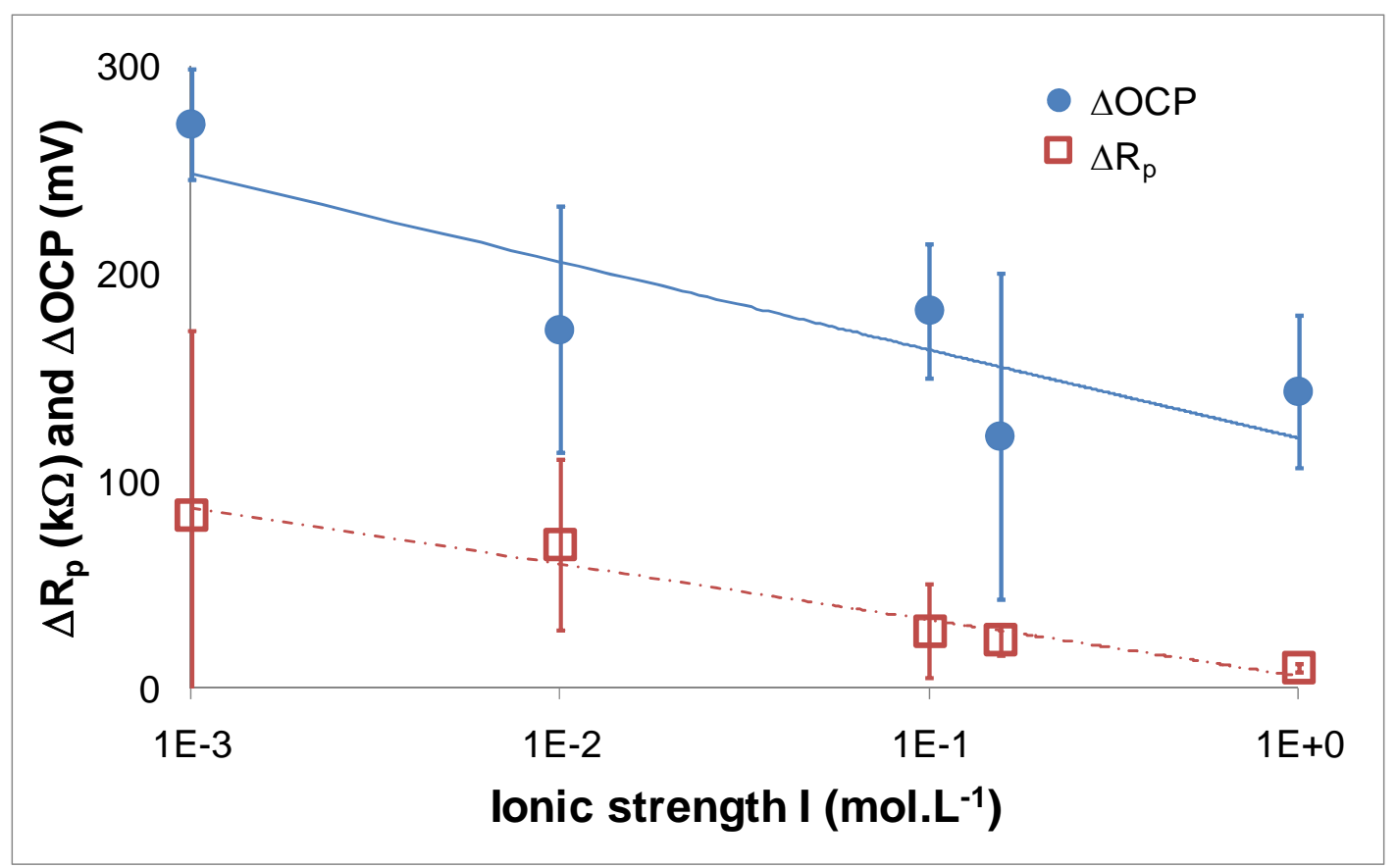

Fig. $5 \Delta \mathrm{R}_{\mathrm{p}}$ : difference between $\mathrm{R}_{\mathrm{p}}$ before fretting and 2400 cycles after fretting start; and $\triangle \mathrm{OCP}$ : difference between OCP before fretting $\left(\mathrm{E}_{\mathrm{bf}}\right)$ and that at the end of fretting test $\left(\mathrm{E}_{\mathrm{ff}}\right)$ versus ionic strength $\mathrm{I}$

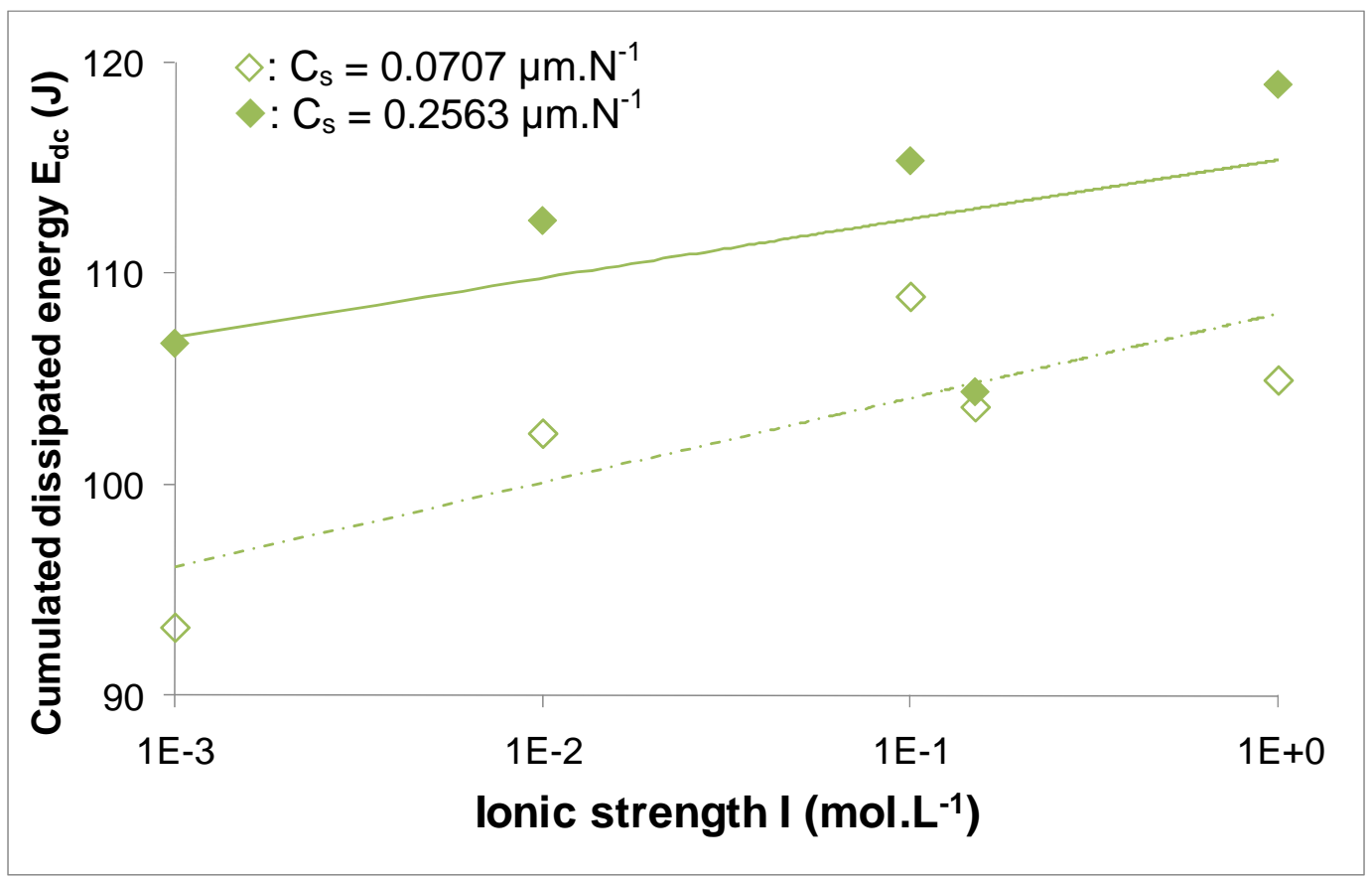

Fig. 6 Cumulated dissipated energy $E_{\mathrm{dc}}$ during the fretting-corrosion test in a function of ionic strength I. Two compliances were investigated, $\diamond: \mathrm{C}_{\mathrm{s}}=0.0707 \mu \mathrm{m} \cdot \mathrm{N}^{-1}$ and $\diamond: \mathrm{C}_{\mathrm{s}}=0.2563 \mu \mathrm{m} \cdot \mathrm{N}^{-1}$ 


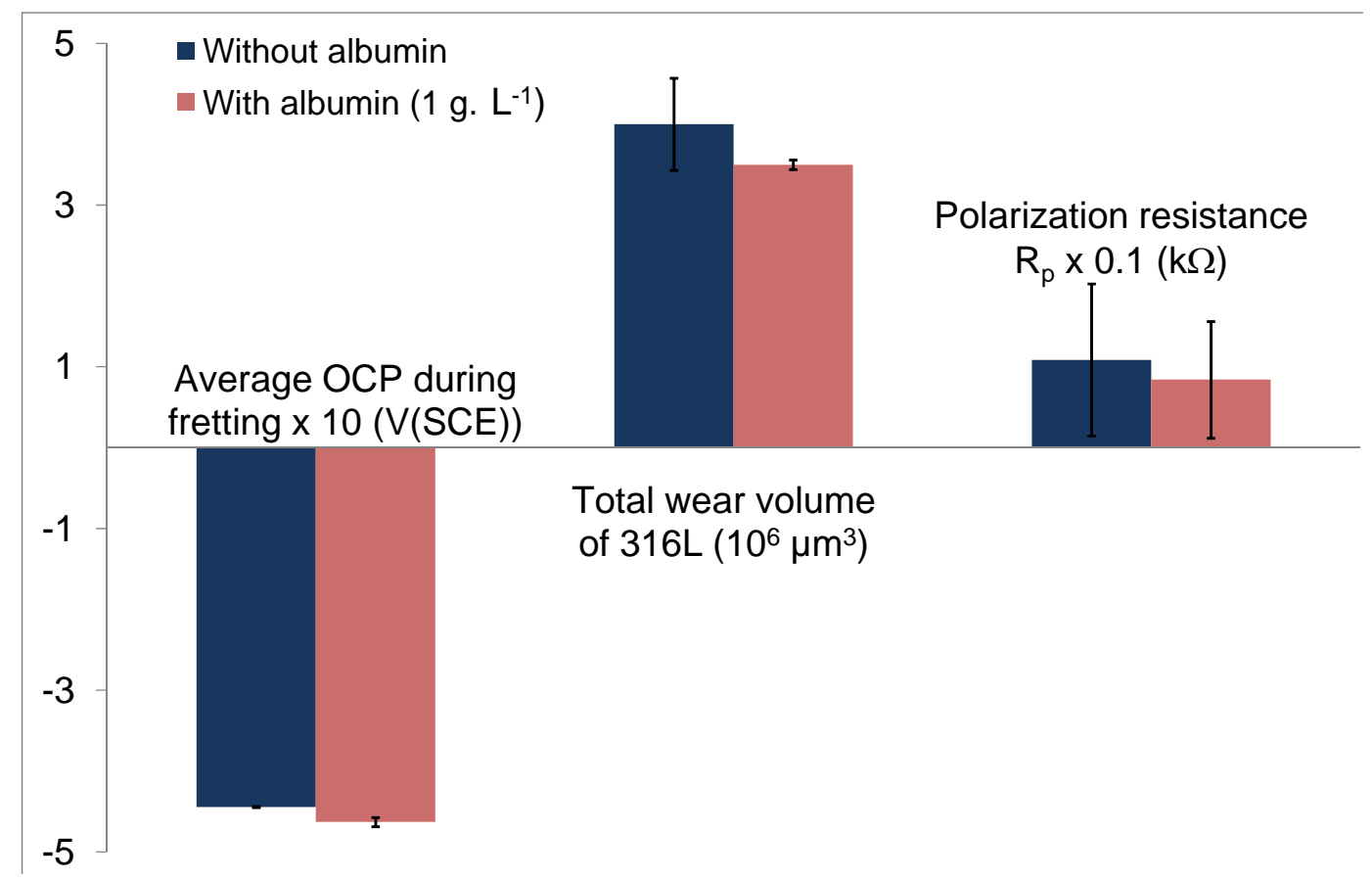

Fig. 7 Influence of albumin (1g. $\left.\mathrm{L}^{-1}\right)$ at OCP conditions on average OCP during fretting, the total wear volume of 316L SS and polarization resistance for $\mathrm{NaCl} 1 \mathrm{~mol} . \mathrm{L}^{-1}$

\subsubsection{Albumin influence}

In order to satisfy in vivo conditions and to understand the role of proteins, experiments were carried out in the same electrochemical conditions and the same solutions with the presence of a protein: albumin with a concentration of 1 g. $\mathrm{L}^{-1}$. As shown on Fig. 7, albumin has no influence (ANOVA test, $\alpha=0.05$ ) on the average value of OCP during fretting and the total material loss for $\mathrm{NaCl} 1 \mathrm{~mol} . \mathrm{L}^{-1}$. $\mathrm{E}_{\mathrm{dc}}, \Delta \mathrm{OCP}$ and $\Delta \mathrm{R}_{\mathrm{p}}$ are not significantly different in cases with and without albumin in $\mathrm{NaCl} 1 \mathrm{~mol} . \mathrm{L}^{-1}$. The same conclusion is highlighted in other solutions. Nevertheless, albumin has influence on wear volume of PMMA: this one is slightly lower with albumin.

\subsubsection{SEM images}

Worn surfaces of 316L SS were observed with a Scanning Electron Microscope (SEM) 6400 JEOL combined with an Energy Dispersive X-Ray (EDX) probe. Fig. 8 presents surfaces of 316L samples submitted to frettingcorrosion tests. Corrosion crevices (Fig. 8 a) are mostly localized at the border of the wear track (Fig. 8 b). At 1 mol. $\mathrm{L}^{-1}$, corrosion seems more localized than that at $10^{-3} \mathrm{~mol} . \mathrm{L}^{-1}$. With albumin, grooves are compacter and corrosion crevices follow friction direction (Fig. 8 c). 

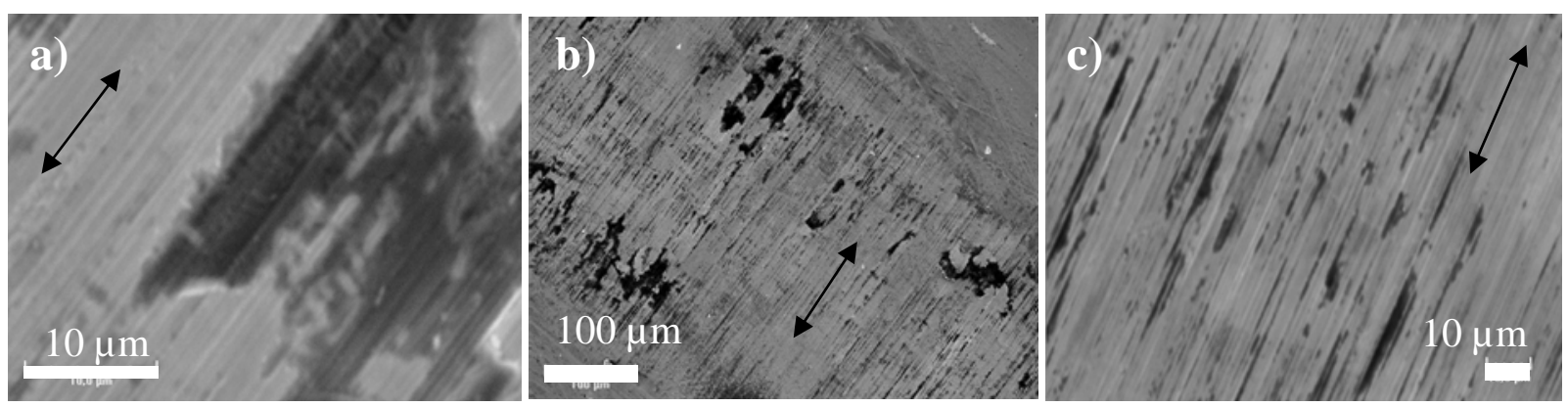

Fig. 8 SEM images of 316L SS in $\mathrm{NaCl} 1$ mol.L ${ }^{-1}$ (a), (b) without albumin (c) with albumin, arrows show the direction of sliding

3.2 Cathodic applied potential conditions $(E=-400 \mathrm{mV}(\mathrm{SCE}))$

At OCP conditions, although we are close to the in vivo conditions, no information on current is available. That's why the second part of this work focuses on cathodic applied potential, and more specifically $E=-400$ $\mathrm{mV}(\mathrm{SCE})$. This value was chosen because the influence of ionic strength on current during fretting can be highlighted.

\subsubsection{Evolution of the current}

Significant values, as the average current during the last 3 hours of fretting $\left(\mathrm{I}_{\mathrm{mf}}\right), \Delta \mathrm{I}$, the difference between the current at the end of fretting $\left(\mathrm{I}_{\mathrm{ff}}\right)$ and the current after fretting $\left(\mathrm{I}_{\mathrm{af}}\right)$, were investigated in accordance with ionic strength. As shown on Fig. 9, fretting involves a higher impact on current values for $\mathrm{NaCl}$ solution of 1 mol.. $\mathrm{L}^{-1}$ $(\Delta \mathrm{I} \sim 11 \mu \mathrm{A})$ than that for $\mathrm{NaCl}$ solution of $10^{-3} \mathrm{~mol}^{-\mathrm{L}^{-1}}(\Delta \mathrm{I} \sim 1 \mu \mathrm{A})$ : the applied potential is enough to protect a surface during friction phase for $\mathrm{NaCl} 10^{-3} \mathrm{~mol} . \mathrm{L}^{-1}$. In the same way, $\mathrm{I}_{\mathrm{mf}}$ is close to zero and is even positive, i.e. anodic for one experiment at $\mathrm{NaCl} 1$ mol. $\mathrm{L}^{-1}$ even though it is cathodic $(\sim-15 \mu \mathrm{A})$ for $\mathrm{NaCl} 10^{-3} \mathrm{~mol} . \mathrm{L}^{-1}$. 


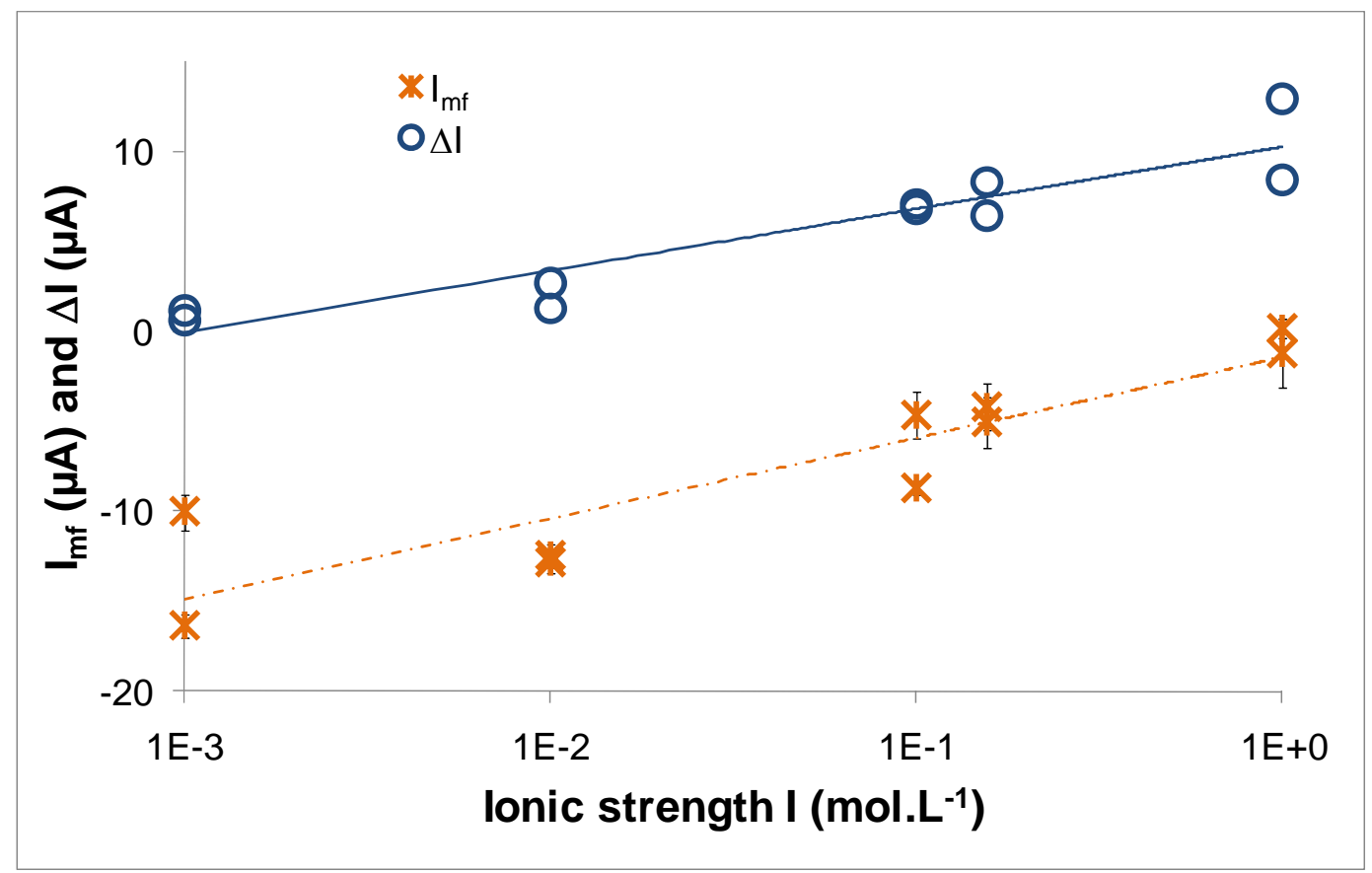

Fig. 9 Average current during fretting-corrosion, $\mathrm{I}_{\mathrm{mf}}$, and difference between current at the end of fretting $\left(\mathrm{I}_{\mathrm{ff}}\right)$ and that after fretting $\left(\mathrm{I}_{\mathrm{af}}\right), \Delta \mathrm{I}$ versus ionic strength $\mathrm{I}$

\subsubsection{Wear volume evolution}

As described in §2.5, wear volumes were measured on PMMA and 316L samples with the Veeco ${ }^{\mathrm{TM}} 3 \mathrm{D}$ optic profilometer (Fig. 10). Wear volume of PMMA is constant whatever the ionic strength (ANOVA test, $\alpha=0.05$ ) at OCP and $\mathrm{E}=-400 \mathrm{mV}(\mathrm{SCE})$ is, but the wear volume of PMMA is slightly higher at OCP conditions.
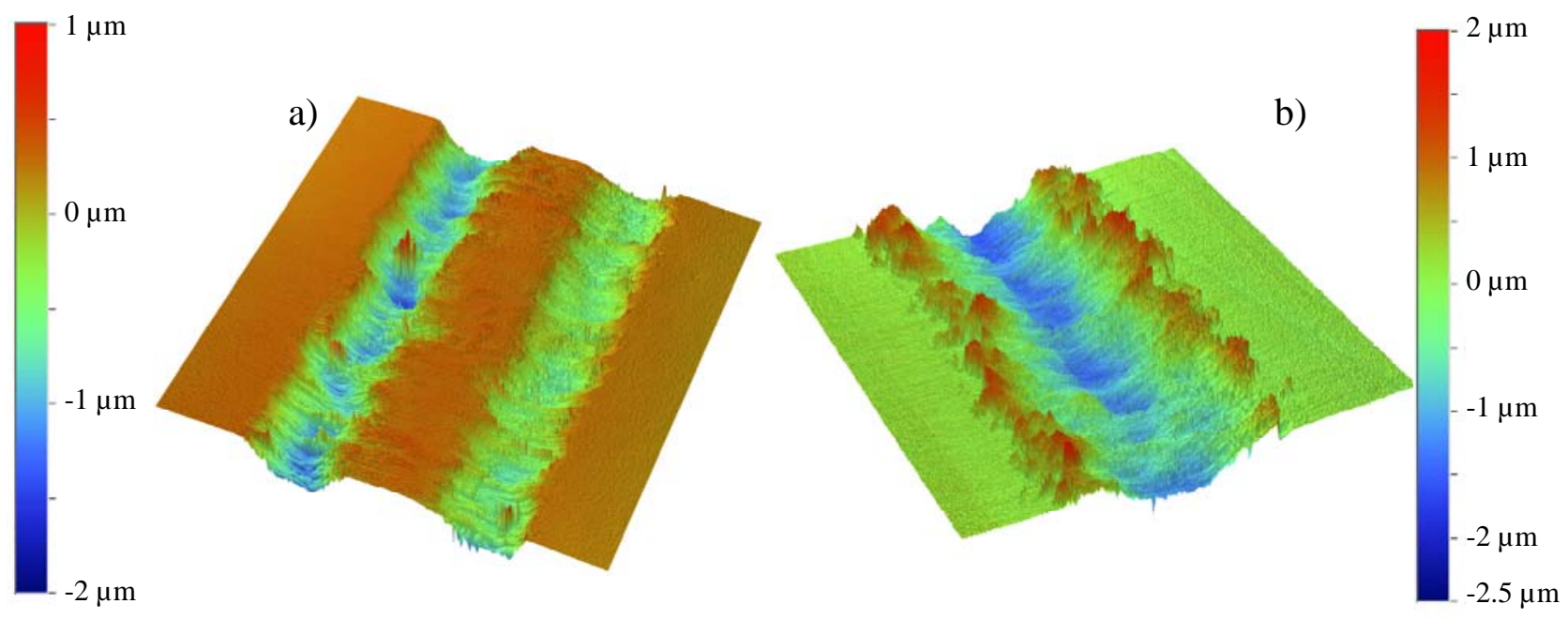
As illustrated on Fig. 11, for 316L samples, total material loss increases with ionic strength for both electrochemical conditions. A threshold concentration is then highlighted, about $10^{-1}$ mol.L $\mathrm{L}^{-1}$. For $10^{-3}$ and $10^{-2}$ mol. $\mathrm{L}^{-1}$, wear volume measured in OCP conditions is higher than that for $\mathrm{E}=-400 \mathrm{mV}(\mathrm{SCE})$. Moreover, for concentrations above $10^{-1} \mathrm{~mol} . \mathrm{L}^{-1}$, wear volume measured in OCP conditions is lower than that at $\mathrm{E}=-400$ $\mathrm{mV}(\mathrm{SCE})$.

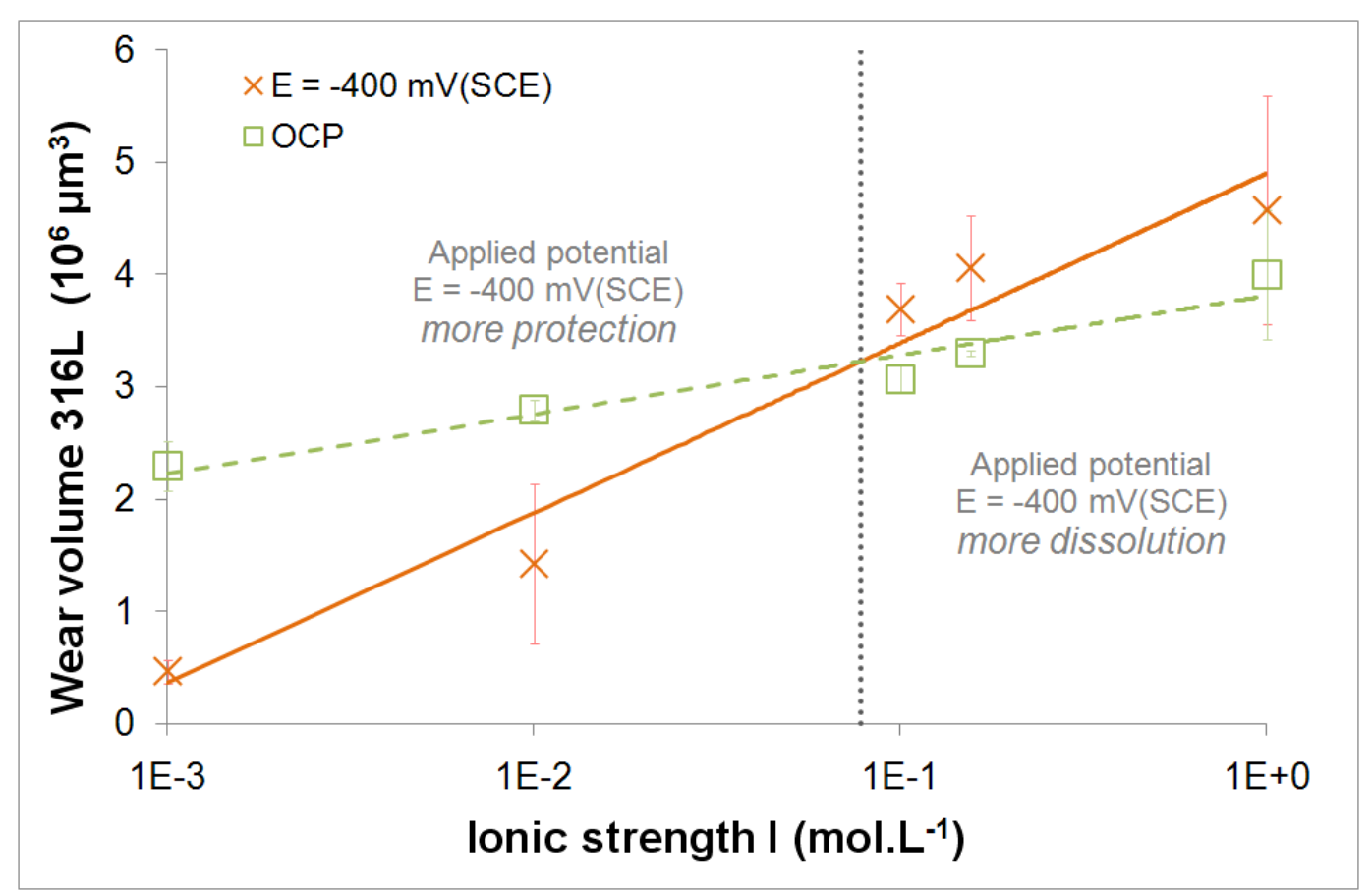

Fig. 11 Total wear volume of 316L versus ionic strength for OCP conditions and $\mathrm{E}=-400 \mathrm{mV}(\mathrm{SCE})$

\subsubsection{Albumin influence}

Contrary to OCP conditions, albumin plays a significant role at the cathodic applied potential of $\mathrm{E}=-400$ $\mathrm{mV}$ (SCE). Mainly, two values are analyzed: the average current during fretting and the percentage of corrosive wear. In $\mathrm{NaCl} 1$ mol.L $\mathrm{L}^{-1}$ (Fig. 12), albumin largely (ANOVA test, $\alpha=0.05$ ) reduces the current during fretting (from $\sim-0.5 \mu \mathrm{A}$ without albumin to $\sim-10 \mu \mathrm{A}$ with albumin) and the percentage of corrosive wear (from $\sim 80 \%$ without albumin to $\sim 50 \%$ with albumin). One may suggest that albumin acts as an anodic inhibitor, as shown by Valero Vidal et al. [14]. 


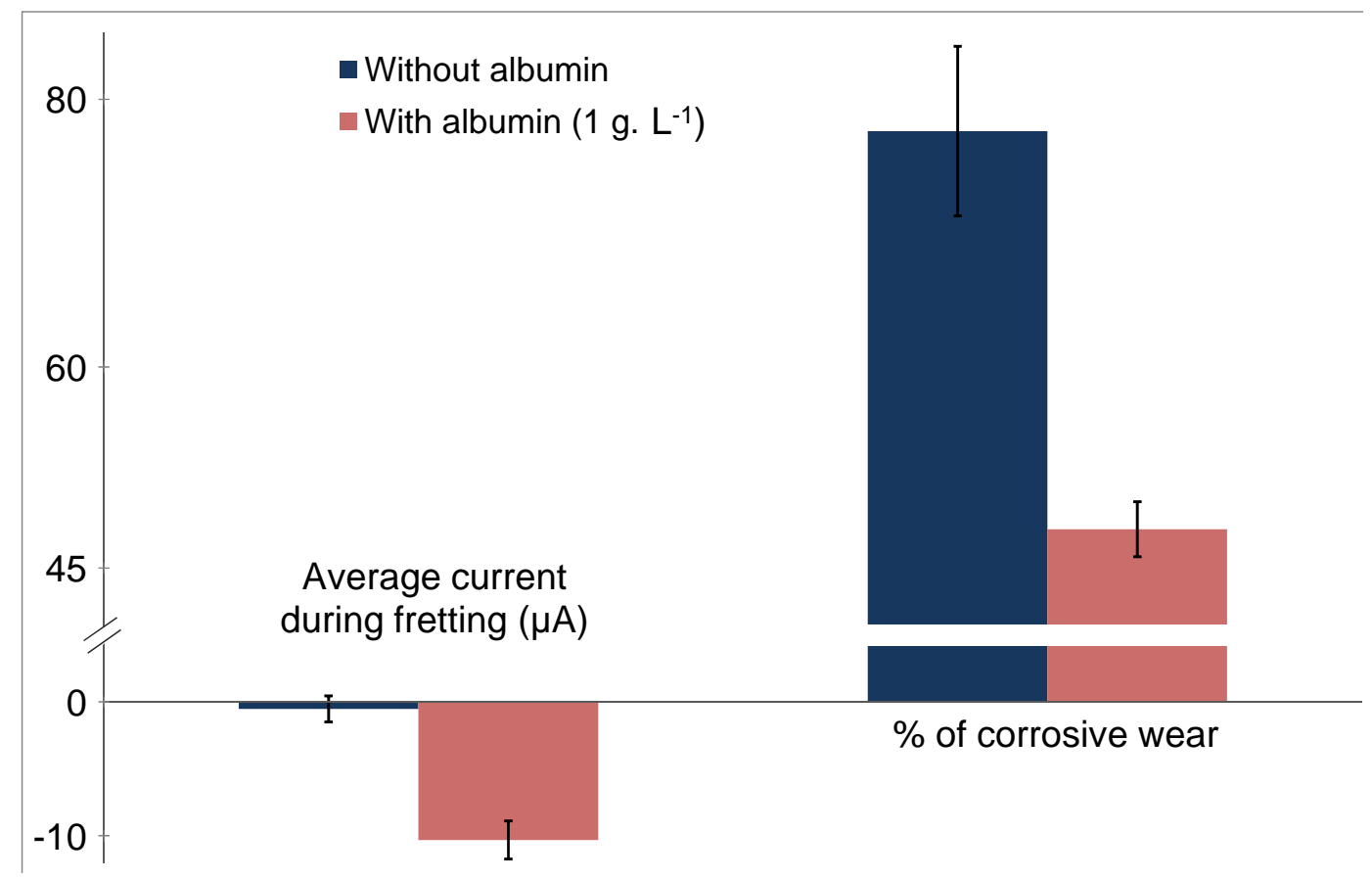

Fig. 12 Influence of albumin (1g. $\left.\mathrm{L}^{-1}\right)$ at $\mathrm{E}=-400 \mathrm{mV}(\mathrm{SCE})$ on average current during fretting and the percentage of corrosive wear of 316L SS for $\mathrm{NaCl}$ solution of 1 mol.. ${ }^{-1}$

\subsubsection{SEM images}

At $\mathrm{E}=-400 \mathrm{mV}(\mathrm{SCE})$, the main difference between Fig. 13 a and Fig. 13 b, i.e. $\mathrm{NaCl} 1$ mol.L $\mathrm{L}^{-1}$ with or without albumin, concerns the grooves inside crevices. Without albumin, grooves indicate that pulled out particles are enough hard to damage surfaces. With albumin, no groove is observed into crevices: particles are probably softer or are ejected more rapidly. At $\mathrm{NaCl} 10^{-3}$ mol.L $\mathrm{L}^{-1}$ (Fig. $13 \mathrm{c}$ ), the central zone of the contact is not damaged and localized corrosion is not observed.
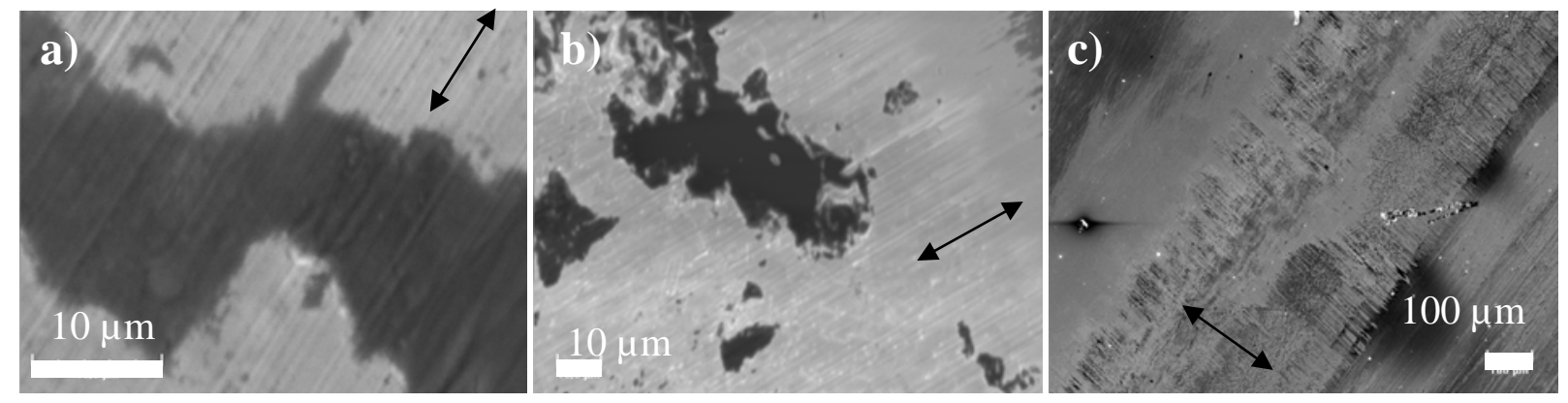

Fig. 13 SEM images of 316L SS in NaCl 1 mol.L-1 (a) without albumin (b) with albumin (c) in $\mathrm{NaCl} 10^{-3}$ mol. $\mathrm{L}^{-1}$ without albumin, arrows show direction of sliding 
To neglect wear due to corrosion and to obtain wear due to mechanical wear $\left(\mathrm{W}_{\mathrm{m}}\right)$, the cathodic potential of $800 \mathrm{mV}$ (SCE) was chosen. To validate this potential value, only extreme ionic strengths $\left(10^{-3}\right.$ and 1 mol. $\left.\mathrm{L}^{-1}\right)$ were tested.

Table 5 Average current during fretting $\mathrm{I}_{\mathrm{mf}}$ and total wear volume $\mathrm{W}$ measured at $\mathrm{E}=-800 \mathrm{mV}(\mathrm{SCE})$, with or without albumin. Influence of albumin and ionic strength is determined by an one-way ANOVA test $(\alpha=0.05)$

\begin{tabular}{|c|c|c|c|c|c|c|}
\hline & \multicolumn{2}{|c|}{$\mathrm{I}_{\mathrm{mf}}(\mu \mathrm{A})$} & \multirow{2}{*}{$\begin{array}{c}\text { Albumin } \\
\text { influence? }\end{array}$} & \multicolumn{2}{|c|}{$\mathrm{W}\left(10^{6} \mu \mathrm{m}^{3}\right)$} & \multirow{2}{*}{$\begin{array}{l}\text { Albumin } \\
\text { influence? }\end{array}$} \\
\hline & without albumin & with albumin & & without albumin & with albumin & \\
\hline $10^{-3} \mathrm{~mol} . \mathrm{L}^{-1}$ & $-17.60 \pm 0.30$ & $-14.93 \pm 0.32$ & YES & $0.25 \pm 0.07$ & $0.19 \pm 0.03$ & NO \\
\hline $1 \mathrm{~mol}^{-\mathrm{L}^{-1}}$ & $-27.96 \pm 9.31$ & $-45.57 \pm 3.11$ & YES & $0.38 \pm 0.14$ & $0.35 \pm 0.08$ & NO \\
\hline $\begin{array}{c}\text { Ionic strength } \\
\text { influence? }\end{array}$ & NO & YES & & NO & NO & \\
\hline
\end{tabular}

As shown on Table 5, the average of current during fretting varies in a function of ionic strength and is modified by the presence or not of albumin. However, the total wear volume is same without regard to the condition (ionic strength and albumin). One may assume that the total wear volume equals the mechanical wear volume $\mathrm{W}_{\mathrm{m}}$, i.e. $\mathrm{W}_{\mathrm{m}}=0.3 \pm 0.110^{6} \mu \mathrm{m}^{3}$.

\section{Discussion}

\subsection{Open Circuit Potential conditions}

The evolution of OCP before, during and after fretting is shown on Fig. 4. One may notice that $E_{b f}$ logarithmically decreases with the ionic strength in accordance with [20]. Chloride ions, $\mathrm{Cl}^{-}$, accelerate anodic dissolution with the formation of an unstable compound $\mathrm{MCl}_{\mathrm{n}}\left(\right.$ or $\left.\mathrm{M}\left(\mathrm{H}_{2} \mathrm{O}\right)_{\mathrm{y}} \mathrm{Cl}_{\mathrm{x}}\right)$ [21]. At high concentration of chloride ions, one may suggest that metallic dissolution is higher and leads to OCP decrease.

The drastic drop of OCP occurs as soon as fretting starts (Fig. 4), expressing the surface degradation. The passive layer on 316L surface is partly destroyed and metal dissolution, i.e. anodic reaction, occurs. In addition, breakdown of the passive layer is highlighted by the polarization resistance $\left(R_{p}\right)$ fall. $R_{p}$ is indeed inversely proportional to corrosion rate (Stern-Geary equation): the $\mathrm{R}_{\mathrm{p}}$ fall involves acceleration of corrosion.

One may notice that these falls, $\Delta \mathrm{OCP}$ and $\Delta \mathrm{R}_{\mathrm{p}}$, decrease with the ionic strength (Fig. 5). According to Macdonald [22], when the concentration of $\mathrm{Cl}^{-}$increases, the passive layer reconstruction becomes more and more difficult. The result highlighted on Fig. 5 translates the difficulty of passive layer reconstruction during fretting when chlorides concentration increases. 
The OCP and $\mathrm{R}_{\mathrm{p}}$ upturn, directly after cessation of fretting (Fig. 4), confirms corrosion activation during fretting test. However, the OCP value after fretting is lower than $\mathrm{E}_{\mathrm{bf}}$. The electrochemical behaviour of 316L surface can indeed be modified by the less protective worn zone and the PMMA and oxides debris deposed on the 316L surface.

From a mechanical point of view, it is worth noting that the cumulated dissipated energy $\left(\mathrm{E}_{\mathrm{dc}}\right)$ during the fretting test increases with the ionic strength (Fig. 6). One may suggest that when the ionic strength increases, attraction between surfaces is reinforced [23].

As shown on Fig. 7, albumin has no influence on the average OCP during fretting and on total wear volume of 316L. Without friction, Valero Vidal et al. [14] showed that albumin does not modify OCP values. At this concentration, 1 g. $\mathrm{L}^{-1}$, albumin does not modify electrochemical behaviour: it has no influence on OCP during fretting and $\mathrm{R}_{\mathrm{p}}$ values; nor on total wear volume.

\subsection{Cathodic applied potential conditions $(E=-400 \mathrm{mV}(\mathrm{SCE}))$}

The applied potential $\mathrm{E}=-400 \mathrm{mV}$ (SCE) is a cathodic potential, i.e. the current is negative, thus the surface is protected against corrosion. However, this protection is not effective for all solutions. For example, in $\mathrm{NaCl} 10^{-3}$ mol. $\mathrm{L}^{-1}$, this protection is effective: $\Delta \mathrm{I} \sim 1 \mu \mathrm{A}$ while it is not effective in $\mathrm{NaCl} 10^{-1}$ or $\mathrm{NaCl} 1 \mathrm{~mol} . \mathrm{L}^{-1}$, respectively $\Delta \mathrm{I} \sim 7 \mu \mathrm{A}$ and $\Delta \mathrm{I} \sim 11 \mu \mathrm{A}$ (Fig. 9). During the fretting-corrosion test, the current even becomes positive, i.e. anodic, for $\mathrm{NaCl} 1$ mol. $\mathrm{L}^{-1}$. In fact, a threshold concentration and two surface behaviours can be determined (Fig. 11). For concentrations below $10^{-1} \mathrm{~mol} \cdot \mathrm{L}^{-1}$, wear volumes at OCP condition are higher than those at $\mathrm{E}=-400$

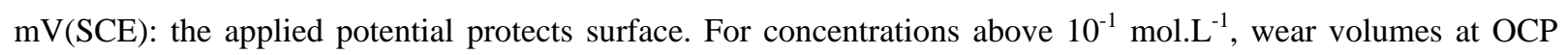
condition are lower than those at $\mathrm{E}=-400 \mathrm{mV}(\mathrm{SCE})$ : the metal dissolution is higher and the passive layer is less protective against fretting. 


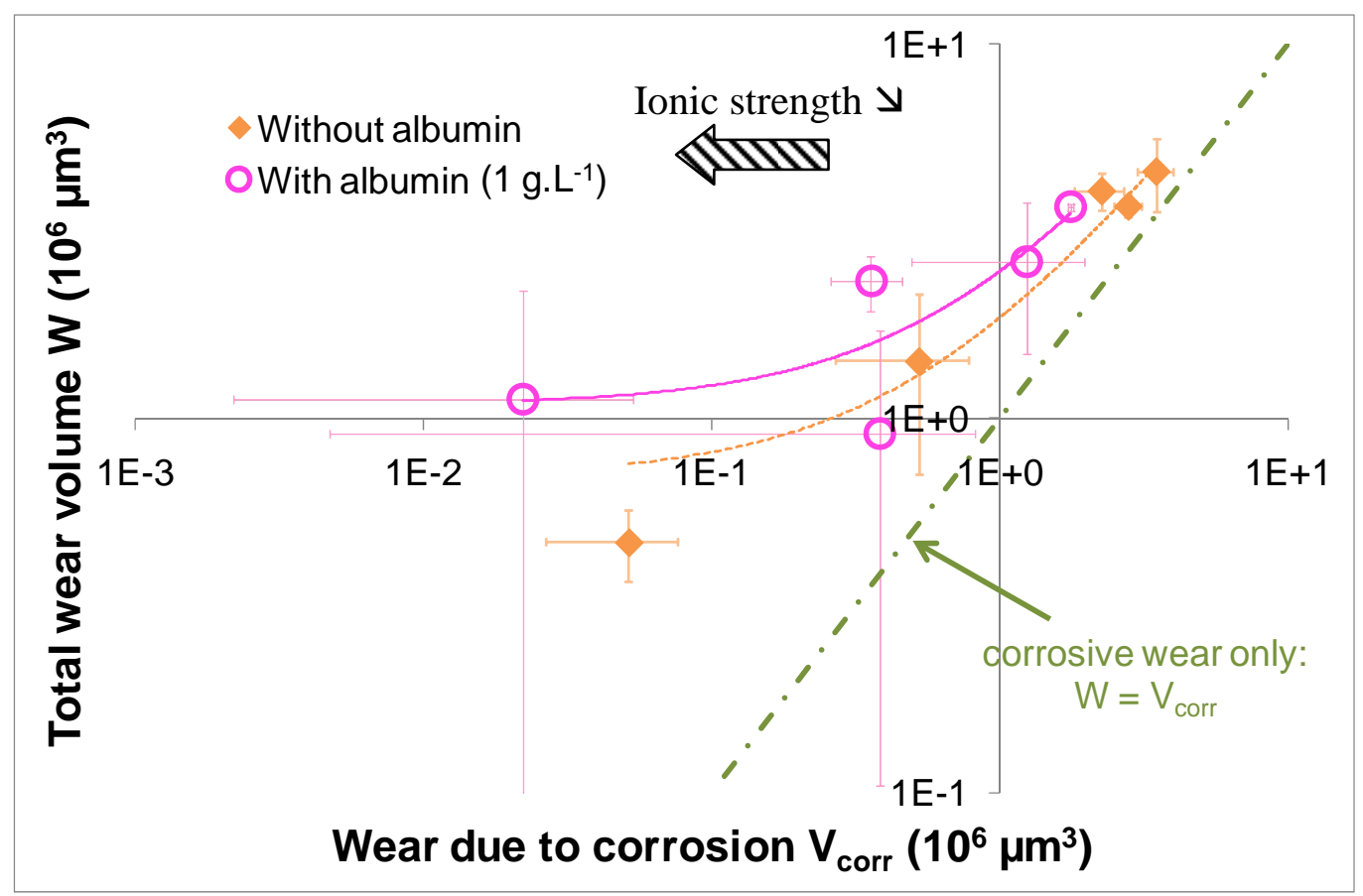

Fig. 14 The total wear volume of $316 \mathrm{~L} \mathrm{SS}, \mathrm{W}$, as a function of wear due to corrosion, $\mathrm{V}_{\text {corr }}$, in the logarithmic scale. The dashed straight line: case where wear is only due to corrosion $\rightarrow \mathrm{W}=\mathrm{V}_{\text {corr. }}$. Ionic strength decreases from the right to the left

Fig. 14 allows underlining which of preponderant wear phenomena is highlighted: corrosion or mechanical wear. Experimental data close to the dashed straight line indicate preponderance of corrosive wear. Corrosion is also the preponderant wear phenomenon for high ionic strength: $~ 80 \%$ in NaCl 1 mol.L ${ }^{-1}$ and $10^{-1} \mathrm{~mol}^{-L^{-1}}$ without albumin. One may notice that, in presence of albumin, the percentage of wear due to corrosion decreases: $\sim 50 \%$ in $\mathrm{NaCl}$ solutions of 1 mol. $\mathrm{L}^{-1}$ and $10^{-1}$ mol. $\mathrm{L}^{-1}$, instead of $80 \%$ without albumin. Especially, in the presence of albumin and for lower ionic strength, standard deviation values are large and the coefficient of variation is in the range from 10 to 100 . The preponderant phenomenon is mechanical wear and in this case, the dispersion of corrosive and total wear values is larger. The main mechanical degradation, under albumin and $\mathrm{NaCl}$ solutions, should involve hazardous wrenching that should be related to the high standard deviation.

\subsection{Cathodic applied potential conditions ( $E=-800 \mathrm{mV}(\mathrm{SCE}))$}

As explained in $\S 1$, the total wear volume of $316 \mathrm{~L}$ SS is the sum of wear due to corrosion, $\mathrm{W}_{\mathrm{c} \text {. and }}$ mechanical wear, $\mathrm{W}_{\mathrm{m}}$. The total wear volume, $\mathrm{W}$, follows the equation (2). At $\mathrm{E}=-800 \mathrm{mV}$ (SCE), no anodic current is measured during a fretting-corrosion test. In this electrochemical condition, anodic dissolution, i.e. metallic dissolution, is neglected without regard to ionic strength and the presence of albumin. The mechanical wear $\mathrm{W}_{\mathrm{m}}$ is also determined: $\mathrm{W}_{\mathrm{m}}=0.3 \pm 0.110^{6} \mu^{3}$. At $\mathrm{E}=-400 \mathrm{mV}$ (SCE), thanks to Faraday's law, the wear due to corrosion $\mathrm{V}_{\text {corr }}$ can be calculated (equation (3)). In fact, in comparison with the total wear volume (equation 
(2)), $\mathrm{V}_{\text {corr }}=\mathrm{W}_{\mathrm{c}}+\Delta \mathrm{W}_{\mathrm{mc}}$. By deduction, the term $\Delta \mathrm{W}_{\mathrm{cm}}$ can be determined, as a function of ionic strength at $\mathrm{E}=-$ $400 \mathrm{mV}$ (SCE). To set apart the synergy term $\Delta \mathrm{W}=\Delta \mathrm{W}_{\mathrm{mc}}+\Delta \mathrm{W}_{\mathrm{cm}}$, the term $\mathrm{W}_{\mathrm{c}}$ must be measured. From polarization resistance values, the dissolution current of the material, $i$, can be calculated: $i=B / R_{p}$, with $B=24$ $\mathrm{mV}$ (hypothesis coming from investigations in the COST 533 round robin). In that way, $\mathrm{W}_{\mathrm{c}}$ is $\sim 100$ or $500 \mu^{3}$ depending on the ionic strength. $\mathrm{W}_{\mathrm{c}}$ represents only $0.01 \%$ of $\mathrm{V}_{\text {corr }}$ and this can be neglected. Iwabuchi et al. found the same ratio: $\mathrm{W}_{\mathrm{c}} / \mathrm{W}$ of $\sim 0.01 \%[25]$.

Fig. 15 a illustrates the contribution of $\Delta \mathrm{W}_{\mathrm{mc}}$, i.e. the increase of corrosive wear due to fretting. Levels can be defined from $\mathrm{NaCl}$ solution of $10^{-1} \mathrm{~mol} . \mathrm{L}^{-1}$ without albumin: above this concentration, the contribution of corrosive wear is about $80 \%$. Albumin at a concentration of 1 g. $\mathrm{L}^{-1}$ shifts the transition and the percentage of corrosive wear: above $10^{-2}$ mol. $\mathrm{L}^{-1}$, the contribution of corrosive wear is constant and about $50 \%$. Thus, albumin decreases the percentage of corrosive wear. One may notice that material behaviour in Ringer solution is different from that in $\mathrm{NaCl}$ solutions. Because of the presence of other ions (Table 3), the contribution of corrosive wear decreases. For example, the role of carbonates could be determined in future work. Fig. $15 \mathrm{~b}$ illustrates the contribution of $\Delta \mathrm{W}_{\mathrm{cm}}$, the increase of mechanical wear due to corrosion. No trend can be defined: mechanical wear is not a function of ionic strength, and this term matches with an arbitrary wrenching in the surface material.
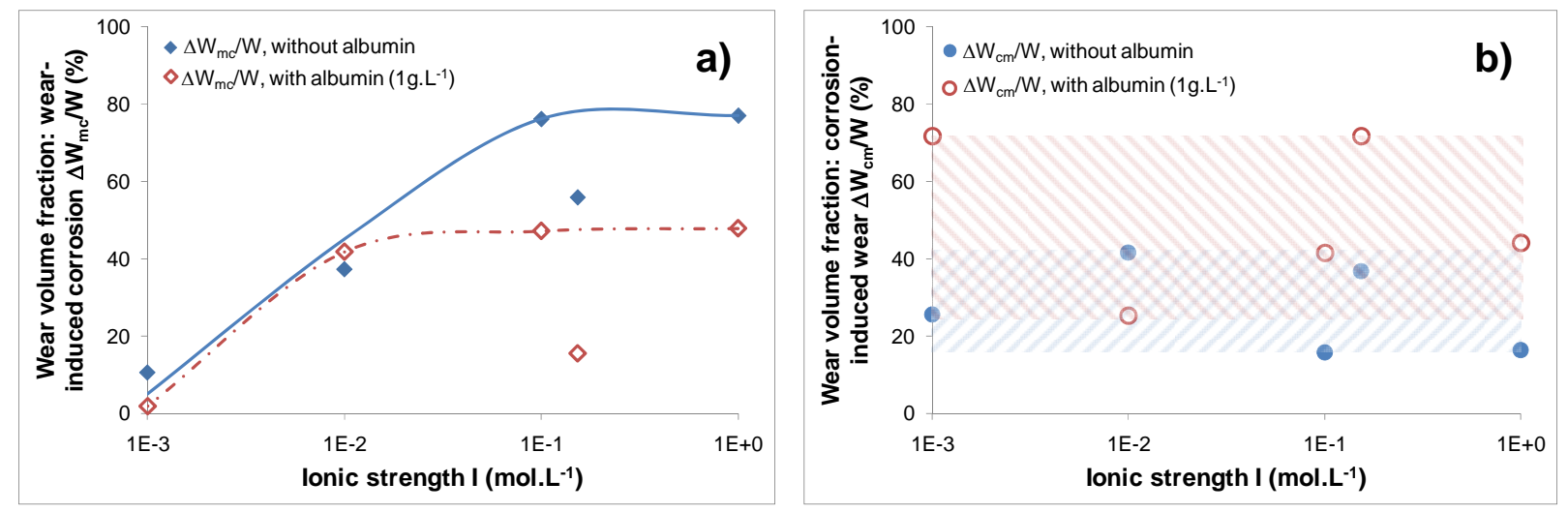

Fig. 15 The contribution of the different synergy terms with albumin (empty symbols) or without albumin (full symbols) :

(a) $\Delta \mathrm{W}_{\mathrm{mc}} / \mathrm{W}$ is the increase of corrosive wear due to fretting and (b) $\Delta \mathrm{W}_{\mathrm{cm}} / \mathrm{W}$ is the increase of mechanical wear due to corrosion

Diomidis et al. [26] worked with a new expression of synergy term. Synergism is in fact the acceleration of material deterioration by corrosion because of mechanical removal and re-growth of a passive layer. Continuous and intermittent sliding tests are completed to measure the material loss in the sliding track. The intermittent sliding tests allow the removal and re-growth of the passive layer. However, the sliding conditions in a frettingcorrosion test are not continuous and the passive layer destruction and re-growth must be different. 
In future work, the influence of albumin concentration on metal behaviour will be studied. To be closer than in vivo conditions, experiments will be realized at 10 and 20 g. $\mathrm{L}^{-1}$. For example, the ISO standard indicates a concentration of proteins equal to 17.5 g.L $\mathrm{L}^{-1}$ for improving the lifetime of hip implants $[27,28]$.

As seen on Fig. 10 a, the characteristic shape of 316L wear track, 'W' wear shape as mentioned in [9,10], is the consequence of crevice corrosion. The evolution of local $\mathrm{pH}$ might lead to this particular shape. The influence of $\mathrm{pH}$ solution could give some information on the crevice corrosion effect. The crevice corrosion effect will be investigated in further investigations.

\section{Conclusions}

Under OCP conditions, the increase of chlorides concentration leads to higher corrosion and a more difficult passive layer reconstruction during the friction phase. From a mechanical point of view, the $E_{d c}$ increases according to the ionic strength; consequently one might suggest attraction between surfaces is reinforced.

At $\mathrm{E}=-400 \mathrm{mV}(\mathrm{SCE})$, a threshold concentration, around $10^{-1} \mathrm{~mol} . \mathrm{L}^{-1}$, highlights that a surface protective phenomenon occurs below this concentration, while more metal dissolution appears above this value.

At $\mathrm{E}=-800 \mathrm{mV}(\mathrm{SCE})$, only the mechanical wear is determined: $\mathrm{W}_{\mathrm{m}}=0.3 \pm 0.110^{6} \mu \mathrm{m}^{3}$. This value is needed to calculate the term of synergy between corrosive and mechanical wear.

Albumin, at 1 g. $\mathrm{L}^{-1}$, has no influence at OCP conditions. However, at $\mathrm{E}=-400 \mathrm{mV}(\mathrm{SCE})$, the percentage of corrosive wear is lower in presence of albumin. Albumin seems to play the role of an anodic inhibitor.

When the chlorides concentration, i.e. the ionic strength in this study, increases, the 316L wear increases too. The most interesting result is: albumin promotes the mechanical degradation compared with the corrosive wear, under cathodic polarization. This assertion includes the pure mechanical degradation and the synergism mechanical wear assisted by the corrosion. One might suggest this synergistic term should be the key-point of the 316L wear, under cathodic polarization.

\section{Acknowledgements}

The authors wish to acknowledge Saint-Etienne Métropole and Conseil Général de la Loire for the financial support. Moreover the authors thank Pr. D.D Macdonald for fruitful discussions and Dr. Kim about reviewing of the English language.

\section{References}

[1] J. Charnley, The long-term results of low-friction arthroplasty of the hip performed as a primary intervention, The Journal of bone and joint surgery. British volume 54 (1972) 61-67.

[2] G. Joshi, S.G. Advani, F. Miller, M.H. Santare, Analysis of a femoral hip prosthesis designed to reduce stress shielding, Journal of Biomechanics 33 (2000) 1655-1662.

[3] F. Langlais, Prothèses totales de hanche. Facteurs biologiques et mécanismes de tolérance, in: F. Langlais, J.P. Delagoutte, Cahiers d’enseignement de la SOFCOT n²4, Expansion scientifique française, 1993, pp. 3-22. 
[4] P. Kovacs, J.A. Davidson, K. Daigle, Correlation between the metal ion concentration and the fretting wear volume of orthopaedic implant metals, Particulate debris from medical implants: mechanisms of formation and biological consequences, ASTM STP 1144, ASTM International, 160-176, 1997.

[5] R.B. Waterhouse, Occurrence of fretting in practice and its simulation in the laboratory, Materials evaluation under fretting conditions, ASTM STP 780, S.R. Brown, 3-16, 1982.

[6] P.J. Rubin, P.F. Leyvraz, L.R. Rakotomanana, Intérêt de la modélisation numérique dans l'évaluation pré-clinique d’une prothèse fémorale de la hanche, Maîtrise Orthopédique 93 (2000) 22-27.

[7] H. Zhang, L.T. Brown, L.A. Blunt, X. Jiang, S.M. Barrans, Understanding initiation and propagation of fretting wear on the femoral stem in total hip replacement, Wear 266 (2009) 566-569

[8] P. Ponthiaux, C. Richard, F. Wenger, Tribocorrosion, Techniques de l’ingénieur, COR60, 2007.

[9] J. Geringer, B. Forest, P. Combrade, Fretting-corrosion of materials used as orthopaedic implants, Wear 259 (2005) 943-951.

[10] J. Geringer, B. Forest, P. Combrade, Wear analysis of materials used as orthopaedic implants, Wear 261 (2006) 971-979.

[11] J. Geringer, B. Forest, P. Combrade, Wear of poly (methyl methacrylate) against a metallic surface in dry conditions, Polymer Engineering \& Science 47 (2007) 633-648.

[12] J. Geringer, F. Atmani, B. Forest, Friction-corrosion of AISI 316L/bone cement and AISI 316L/PMMA contacts: Ionic strength effect on tribological behaviour, Wear 267 (2009) 763-769.

[13] M.L.C.A. Afonso, R.F.V. Villamil Jaimes, E.P.G. Arêas, M.R. Capri, E. Oliveira, S.M.L. Agostinho, The influence of albumin on the anodic dissolution of chromium present in UNS S31254 stainless steel in chloride environment, Colloids and Surfaces A: Physicochemical and Engineering Aspects 317 (2008) 760-763.

[14] C. Valero Vidal, A. Igual Muñoz, Electrochemical characterisation of biomedical alloys for surgical implants in simulated body fluids, Corrosion Science 50 (2008) 1954-1961.

[15] S. Hiromoto, S. Mischler, The influence of proteins on the fretting-corrosion behaviour of a Ti6Al4V alloy, Wear 261 (2006) $1002-1011$. [16] S.W. Watson, F.J. Friedersdorf, B.W. Madsen, S.D. Cramer, Methods of measuring wear-corrosion synergism, Wear 181-183 (1995) 476484.

[17] J. Jiang, J. Stack, Modelling sliding wear: from dry to wet environments, Wear 261 (2006) 954-965.

[18] S. Fouvry, P. Kapsa, L. Vincent, Quantification of fretting damage, Wear 200 (1996) 186-205.

[19] J. Geringer, B. Normand, C. Alemany-Dumont, and R. Diemiaszonek, Assessing the tribocorrosion behaviour of $\mathrm{Cu}$ and $\mathrm{Al}$ by electrochemical impedance spectroscopy, Tribology International 43 (2010) 1991-1999.

[20] Y. Zhang, D.D. Macdonald, M. Urquidi-Macdonald, G.R. Engelhardt, R. Barry Dooley, Passivity breakdown on AISI type 403 stainless steel in chloride-containing borate buffer solution, Corrosion science 48 (2006) 3812-3823.

[21] T.P. Hoar, W.R. Jacob, Breakdown of passivity of stainless steel by halide ions, Nature 216 (1967) 1299-1301.

[22] D.D. Macdonald, Passivity-the key to our metals-based civilization, Pure Applied Chemistry 71 (1999) 951-978.

[23] R.J. Brigham, Crevice corrosion initiation and the potential of zero charge, Corrosion Science 29 (1989) 995-1001.

[24] J. Gavoille, J. Takadoum, Surface charges and adhesion measured by atomic force microscope influence on friction force, Tribology International 36 (2003) 865-871.

[25] A. Iwabuchi, J.W. Lee, M. Uchidate, Synergistic effect of fretting wear and sliding wear of Co-alloy and Ti-alloy in Hanks' solution, Wear 263 (2007) 492-500.

[26] N. Diomidis, J.P. Celis, P. Ponthiaux and F. Wenger, Tribocorrosion of stainless steel in sulfuric acid: Identification of corrosion-wear components and effect of contact area, Wear 269 (2010) 93-103.

[27] ISO 14243-1, Implants for surgery—-wear of total knee joints prosthesis. Part 1. Loading and displacement parameters for wear-testing machines and corresponding environmental conditions for test.

[28] ISO 14243-3, Implants for surgery—wear of total knee joints prosthesis. Part 3. Loading and displacement parameters for wear-testing machines with displacement control and corresponding environmental conditions for test. 